\title{
Effect of capillin foliar spray on productivity and quality of sugar beet varieties.
}

\author{
*Mubarak M. H. ${ }^{1}$ and Deaa M. Abd El Rahman ${ }^{2}$ \\ ${ }^{1}$ Faculty of Agricultural and Environmental Sciences, Plant production department (Agronomy branch), \\ Arish University. \\ 2 pharmacist, Ministry of health \\ *Corresponding author: mubarakmohamed712@gmail.com
}

Received on: 11/5/2020

Accepted on: 21/5/2020

\begin{abstract}
Capillin produced from Artemisia monosperma family Asteraceae. Capillin has strong antifungal activity, and it is possibly antitumor. Capillin exhibits cytotoxic activity and causes apoptosis of certain tumorcells. The aim of the investigation is to study the effect of Capillin foliar spray on productivity and quality of sugar beet varieties under stres $\mathrm{s}$ of salinity and lack of chemical fertilizers. In these trials no urea, no hormones no pesticides, no fungicides were us ed. More long shelf life of vegetables and fruits because plants treated with capillin are organic.

The experimental design was split-plot in (RCBD) with four replications. The main plots were devoted to varieties, whereas Capillin levels treatments were in sub-plots. The performance of four sugarbeet varie ties (cvs.); Samba, Pleno, Poly belga and Gloria was studied to es timate sugar yield and quality under the fourCapillin levels .

The effect of Capillin levels was significant. Samba variety at $500 \mathrm{ppmCapillin}$ level had the hig hest s ugar extraction as well as sugar yield/fed. Using Capillin attained high productivity, ratio of sucrose productivity achieved up to $239 \%$.
\end{abstract}

KEYWORDS: Capillin, sugar percentage, yield, Salinity, sugar beet, Beta vulgaris L.

\section{Introduction}

Sugar beet is considered one of the most familiar sugar crops it is a temperate crop; however, it can be grown in a wide range of climatic level. Sugar beet contains sucrose up to $21 \%$ (Memon et al., 2004). Sugar beet root yield varied between 5000-9000 $\mathrm{kg} / \mathrm{ha}($ Feddan $(\mathrm{fed})=0.42$ hectare $(\mathrm{ha}))$ and sugar content varied between 12 and $16 \%$ according to growing level and climate changes (Turgut, 2012). The importance of sowing sugar beet is not only confined to sugar production, but also to its wide adaptability to be grown in poor, saline, alkaline and calcareous soils. Also, increasing sugar productivity could be achieved through developing appropriate new technical package for growing sugar beet that included management agronomic practices to improve yield and quality of sugar beet (Beta vulgaris $L$.) such as fertilization program, which are the most important factors that affect the quantity and quality (Azzazy et al., 2007). Capillin increases rate of mitosis of stem cells with consequent increase in leaf surface area which leads to more photosynthesis and more carbohydrate and energy production that counteracts high osmotic pressure of saline water. Capillin is a friend of environment, it is used as antimicrobial, antioxidant, cytotoxic, insecticidal, antivenomous, and many other pharmacological effects(Whelan and Ryan, 2004).. The imbalanced continuous use of synthetic fertilizers may result in micronutrient deficiencies, which is becoming a major, constrain for productivity, stability and sustainability of soil health. Thus, the advantages need to integrate use of inorganic, organic and biofertilizer in order to make optimum use of each and achieve balanced nutrient management for optimum crop growth (Selim and Al-Jawhara, 2017).

Keeping in consideration the previous researches that previously mentioned, the present study aims to evaluate the effect of Capillin as grow th regulators on the growth rate of sugar beet varieties under North Sinai conditions.

\section{Materials and Methods}

Field experiment was carried out at the Experimental Farm, Faculty of Environmental Agricultural Sciences (FEAS), EL-Arish, Arish University, North Sinai Governorate during two winter seasons of 2017-18 and 2018-19. Sugar beet multi germ sugar beet Samba, Pleno, Polybelga and Gloria were sown on the fifth October in the first and second seasons (at rate of $4 \mathrm{~kg} \mathrm{fed}^{-1}$ ). Seeds were obtained from Sugar Crops Research Institute, Agric., Research Center, Ministry of Agric, Egypt. The experimental design was split-plot in randomized complete block design (RCBD) with four replications. Plot area was $8 \mathrm{~m} 2$ (1/500 fed-1) containing 4 rows of $4 \mathrm{~m}$ length $(50 \mathrm{~cm}$ between rows and $20 \mathrm{~cm}$ between plants). Main plot were used varieties (Samba, Pleno, Polybelga and Gloria). 
Scientific Journal of Agricultural Sciences 2 (1):15-25, 2020

Sub- plot were used four Capillin treatments (Without Capillin (control), 250,375 and 500 ppm). Capillin were used as foliar application for 4 times in both seasons, One month intervals.

The first one after 60 days from sowing was spared. The previous crop was sowing in same area in the summer guar (Cyamopsis tetragonoloba) in the first and second seasons, respectively Seeds After one month, the plants were thinned to two plants per hill, and then were singled to one plant per hill after 45 days from sowing. Drip irrigation system was used. The experiment site was irrigated immediately just after seeding and thereafter, irrigation every 6 days by underground saline water (3550 ppm) pumped from a well from sowing was applied. All The other cultural practices were practiced as recommended for cultivation in North Sinai sugar beet. Before commencement experiments, Samples of soil sites and irrigation water were taken analy sis according the methods described by (Richard, 1954).
Table 1: show the experiment treatments.

\begin{tabular}{ll}
\hline main plot & sub plot \\
\hline \multirow{3}{*}{ Samba } & Without Capillin ( Control ) \\
& Capillin (250 ppm) \\
& Capillin (375ppm) \\
& Capillin (500 ppm) \\
& Without Capillin ( Control ) \\
& Capillin (250 ppm) \\
Pleno & Capillin (375ppm) \\
& Capillin (500 ppm) \\
& Without Capillin ( Control ) \\
Gloria & Capillin (250 ppm ) \\
& Capillin (375ppm) \\
& Capillin (500 ppm) \\
& Without Capillin ( Control ) \\
& Capillin (250 ppm ) \\
Polybelga & Capillin (375ppm) \\
& Capillin (500 ppm)
\end{tabular}

Table 2: Chemical analyses of the irrigation water in season 2017/2018.

\begin{tabular}{|c|c|c|c|c|c|c|c|c|c|c|}
\hline \multirow{3}{*}{ pH } & \multirow{2}{*}{\multicolumn{2}{|c|}{ EC }} & \multicolumn{8}{|c|}{ Soluble ions (mq/l) } \\
\hline & & & \multicolumn{5}{|c|}{ Cations } & \multicolumn{3}{|c|}{ Anions } \\
\hline & d.sm ${ }^{-1}$ & Ppm & $\mathbf{C a}^{++}$ & $\mathbf{M g}^{++}$ & $\mathrm{Na}^{+}$ & $\mathbf{K}^{+}$ & $\mathrm{Cl}^{-}$ & $\mathrm{Hco}_{3}{ }^{-}$ & $\mathrm{Co}_{3}^{--}$ & $\mathrm{So}_{4}^{--}$ \\
\hline 6.6 & 5.55 & 3550 & 17.22 & 19.17 & 17.29 & 2.31 & 37.51 & 5.21 & - & 13.27 \\
\hline
\end{tabular}

Table 3: Chemical analyses of the irrigation water in season 2018/2019.

\begin{tabular}{|c|c|c|c|c|c|c|c|c|c|c|}
\hline \multirow{3}{*}{ pH } & \multirow{2}{*}{\multicolumn{2}{|c|}{ EC }} & \multicolumn{8}{|c|}{ Soluble ions (mq/l) } \\
\hline & & & \multicolumn{5}{|c|}{ Cations } & \multicolumn{3}{|c|}{ Anions } \\
\hline & d.sm ${ }^{-1}$ & Ppm & $\mathbf{C a}^{++}$ & $\mathbf{M g}^{++}$ & $\mathrm{Na}^{+}$ & $\mathbf{K}^{+}$ & $\mathrm{Cl}^{-}$ & $\mathrm{Hcos}_{3}^{-}$ & $\mathrm{Co}_{3}{ }^{--}$ & $\mathrm{So}_{4}^{--}$ \\
\hline 6.6 & 5.63 & roo. & 19.21 & 18.87 & 14.87 & 2.14 & 39.51 & 2.41 & - & 13.09 \\
\hline
\end{tabular}

During seed bed preparation, $60 \mathrm{~kg}$ P2O5per fed was added in the form of super phosphate (15.5\% P2O5). Moreover, $60 \mathrm{~kg} \mathrm{~N} / \mathrm{fed}$ was added in the form of ammonium nitrate $(33.5 \% \mathrm{~N})$ in two equal doses (after thinning, which was done at 4- leaves stage to one plant per hill) and four weeks later. Moreover, $50 \mathrm{~kg} \mathrm{~K} 2 \mathrm{O}$ per fed was applied with the 1 st nitrogen dose in the form of potassium sulfate $(48 \% \mathrm{~K} 2 \mathrm{O})$. Other agronomic practices were carried out as recommended in sugar beet fields.

The following characters were studied:

\section{1. Juice Quality:}

At harvest, sample of thirty roots was taken at random from each plot and sent to Sugar factories to determine the following parameters:

2.1.1. Impurities characteristics:

2.1.1.1. Potassium and sodium percentages were determined in the digested solution using "Flamephotometer" according to the method described by Brown and Lilliand (1964) and Sirsat et al. (2017).

2.1.1.2. Alpha amino nitrogen percentage was determined using "Hydrogenation" method described by Carruthers et al. (1962) and Mousa et al. (2015). 2.1.2. Quality traits.

2.1.2.1 Sucrose percentage (Pol. \%) was polar metrically determined in a lead acetate extract of fresh minced root according to AOAC' (1995) and Aly and Khalil (2017.(

2.1.2.2 Purity percentage, which was calculated according the following equation (Devillers) 1988, Abashadyet al.,2011. 
Mubarak M. H. and Deaa M. Abd El Rahman., 2020

Table 4. physical and Chemical analysis of the experimental soil during the two seasons.

\begin{tabular}{ccc}
\hline Soil properties & Season & Season \\
\hline Coarse sand \% & $\mathbf{2 0 1 7 / 2 0 1 8}$ & $\mathbf{2 0 1 8} / \mathbf{2 0 1 9}$ \\
Fine sand \% & 60.28 & 58.26 \\
Silt \% & 19.66 & 17.74 \\
Clay \% & 11.39 & 14.36 \\
soil texture & 8.67 & 9.64 \\
Organic matter \% & Loamy sand & Loamy sand \\
Chemical analysis in extraction soil & 0.21 & 0.22 \\
a) Cations (mq/l) & & \\
Ca++ & & 3.03 \\
Mg++ & 3.01 & 2.21 \\
Na+ & 2.22 & 3.75 \\
K+ & 3.82 & 0.51 \\
b) Anion (mq/l) & 0.45 & 2.11 \\
HCO3 & & 2.17 \\
Cl- & 2.12 & 3.33 \\
SO4 & 2.23 & 1.79 \\
CaCO3 \% & 3.27 & 4.25 \\
EC (ds/m) (1:5) & 1.78 & 8.15 \\
pH (1:2.5) & 4.05 & \\
\hline
\end{tabular}

Purity\% $=99.36-14.27(\mathrm{Na}+\mathrm{K}+\alpha$-amino N)/sucrose $\%$.

2.1.2.3. Sugar lost to molasses percentage (SM \%) was determined using the following equation described by Devillers (1988) and Abashady et al. (2011):

Sugar lost to molasses $(\mathrm{SM} \%)=0.14(\mathrm{Na}+\mathrm{K})+$ $0.25(\alpha$-amino $\mathrm{N})+0.50$

2.1.2.4 Extractable sugar percentage, which was calculated according the equation of Dexter et al. (1967)and Abashadyet al. (2011) as follows:

Extractable sugar $(\%)=$ sucrose $(\%)-$ SM $\%-0.6$

2.1.2.5. Extractability percentage, which was determined the equation shown by Dexter et al. (1967) and Abashady et al. (2011):

Extractability $(\%)=$ Sugar extraction/Sucrose $(\%)$

2.2. Sugar beet yields:

At harvest, all plants in each plot were uprooted, separated into roots and tops and weighed to estimate the following:

1. Root yield/fed (ton).

2. Sugar yield/fed (ton), which was calculated according to the following equation:

Sugar yield $=$ root yield/fed (ton) $\mathrm{x}$ extractable sugar $(\%)$.

3. Sugar yield ratio, which was calculated according to the following equation:

Sugar yield ratio $(\%)=$ Sugar yield $/$ control treatment $\mathrm{x} 100$

\subsection{Statistical analysis: \\ Split-plot in randomized complete block design (RCBD) with four replic ations was used. The obtained data was subjected to statistical analysis of variance according to (Snedecor and Cochran, 1990). A combined analysis for the studied levels and seasons was done according to Gomez and Gomez (1984). The treatment means were compared using LSD values at 5\% level of significance. Data analysis was performed by SPSS Computer Statistic ally Analysis Program V.20.}

\section{Results and Discussion \\ 3.1. Juice quality \\ 3.1.1. Characteristics of impurities:}

It is well known from the industrial view that there is an inverse relationships between juice quality and the values of impurities in terms of percentages of potassium (K \%), sodium ( $\mathrm{Na} \%$ ) and $\alpha$ - Amino nitrogen. In the following we will study the values of impurities percentages to throw some light on juice quality.

\subsubsection{Potassium percentage (K\%) in roots:}

Results in Table (5) show the effect of the four Capillin levels (Control, 250, 375 and 500 ppm) on root potassium percentage of four sugar beet varieties in 2017/2018 and 2018/2019 seasons. The results in Table (5) cleared that growing sugar beet at Control Capillin level resulted in roots contained signific antly higher potassium percentage compared to those grown at 375 and $500 \mathrm{ppm}$. This result may 
Scientific Journal of Agricultural Sciences 2 (1):15-25, 2020

Table 5. Potassium percentage ( $\mathrm{K} \%$ ) of four sugar beet varieties as affected by Capillin level in $2017 / 2018$ and $2018 / 2019$ seasons.

\begin{tabular}{|c|c|c|c|c|c|c|c|c|}
\hline \multirow{3}{*}{$\begin{array}{l}\text { Season } \\
\text { Variety } \\
\end{array}$} & \multicolumn{6}{|c|}{$2017 / 2018$} & \multicolumn{2}{|c|}{$2018 / 2019$} \\
\hline & \multicolumn{8}{|c|}{ Capillin levels } \\
\hline & Control & 250 & 375 & 500 & Control & 250 & 375 & $500 \mathrm{ppm}$ \\
\hline Samba & 3.14 & 3.14 & 2.73 & 2.00 & 3.27 & 3.09 & 2.90 & 2.09 \\
\hline Pleno & 3.25 & 3.16 & 2.82 & 3.08 & 3.33 & 3.04 & 2.76 & 2.04 \\
\hline Gloria & 2.96 & 3.04 & 2.64 & 2.88 & 3.14 & 2.93 & 2.72 & 2.03 \\
\hline Polybelga & 2.79 & 2.65 & 2.56 & 2.67 & 3.07 & 2.82 & 2.57 & 2.02 \\
\hline \multicolumn{9}{|l|}{ L.S.D at $0.05 \%$} \\
\hline $\begin{array}{c}\text { Capillin levels } \\
\text { (L) }\end{array}$ & \multicolumn{4}{|c|}{0.130} & \multicolumn{4}{|c|}{0.080} \\
\hline Varieties (V) & \multicolumn{4}{|c|}{$\begin{array}{l}0.180 \\
0310\end{array}$} & \multicolumn{4}{|c|}{0.110} \\
\hline $\mathbf{L} \times \mathbf{V}$ & \multicolumn{4}{|c|}{0.310} & \multicolumn{4}{|c|}{0.190} \\
\hline
\end{tabular}

be attributed to potassium percentage content of soil. Similar results were reviewed by Abd El-Razek et al. (2006), Aly (2006), Allam et al. (2007) and Khalil et al. (2019.(

The maximum potassium $(3.25 \%)$ was recorded by Pleno sugar beet variety under control Capillin level, while the minimum potassium $(2.00 \%)$ was reported by Samba sugar beet variety under 500 ppm Capillin level .

The results showed significant differences among the tested sugar beet varieties in potassium percentage in roots. Pleno variety recorded the highest value of this trait. On the other hand, samba variety had the lowest potassium percentage in the first season $(2.00 \%)$, while Polybelga variety had the lowest potassium percentage in the second season $(2.02 \%)$, when they treated with 500 ppm.capillin

The results are in agreement with those of Abd El-Kader (2011) stated that the effect of growth regulators application(Mepiquate Chloride (pix) and Indole acetic acid (IAA)) on decreasing potassium percentage under nitrogen fertilization equal $70 \mathrm{~kg}$

Table 6. Sodium percentage of four sugar beet varieties as affected by Capillin level in 2017/2018and 2018/2019 seasons.

\begin{tabular}{|c|c|c|c|c|c|c|c|c|c|}
\hline \multirow{3}{*}{$\begin{array}{l}\text { Season } \\
\text { Variety } \\
\end{array}$} & \multirow{2}{*}{\multicolumn{4}{|c|}{$\begin{array}{l}2017 / 2018 \\
\text { Capillin levels }\end{array}$}} & \multicolumn{5}{|c|}{ 2018/2019 } \\
\hline & & & & & & & & & \\
\hline & \multicolumn{2}{|c|}{ Control250 } & \multirow{2}{*}{$\begin{array}{l}375 \\
1.52\end{array}$} & \multirow{2}{*}{$\frac{500}{1.22}$} & \multicolumn{2}{|c|}{ Control 250} & \multirow{2}{*}{$\frac{375}{2.15}$} & \multirow{2}{*}{$\frac{500}{1.84}$} & \multirow[t]{2}{*}{ ppm } \\
\hline$\overline{\text { Samba }}$ & 2.76 & 2.38 & & & 2.38 & 2.22 & & & \\
\hline Pleno & 2.63 & 2.23 & 1.37 & 1.08 & 2.35 & 2.30 & 2.07 & 1.57 & \\
\hline Gloria & 2.56 & 2.22 & 1.25 & 1.01 & 2.25 & 2.02 & 1.94 & 1.55 & \\
\hline Polybelga & 2.78 & 2.37 & 1.54 & 1.22 & 2.44 & 2.28 & 2.15 & 1.73 & \\
\hline \multicolumn{10}{|l|}{ L.S.D at $0.05 \%$} \\
\hline Capillin levels (L) & \multicolumn{4}{|c|}{0.090} & \multicolumn{5}{|c|}{0.080} \\
\hline Varieties (V) & \multicolumn{4}{|c|}{0.010} & \multicolumn{5}{|c|}{0.110} \\
\hline $\mathbf{L} \times \mathbf{V}$ & \multicolumn{4}{|c|}{0.210} & \multicolumn{5}{|c|}{0.190} \\
\hline
\end{tabular}

Polybelga and Samba varieties recorded the highest value of this trait. On the other hand, Gloria variety had the lowest sodium percentage in roots. The fed-1 and soil salinity equal $900 \mathrm{ppm}$ at $200 \mathrm{ppm}$ IAA potassium percentage $(3.08 \%)$. Pix at $(2000$ ppm) under nitrogen fertilization equal $70 \mathrm{~kg}$ fed-1 and soil salinity equal $900 \mathrm{ppm}$ attained $(2.6190 \%)$ potassium percentage. On the other hand, $500 \mathrm{ppm}$ Capillin recoded the lowest potassium percentage $(2.00 \%)$ under nitrogen fertilization equal $60 \mathrm{~kg}$ fed1 , soil salinity equal $2720 \mathrm{ppm}$ and water of irrigation salinity equal $3550 \mathrm{ppm}$.

3.1.1.2. Sodium percentage $(\mathrm{Na} \%)$ in roots:

Results in Table (6) show the effect of the four Capillin levels (Control, 250, 375 and 500 ppm) on sodium percentage in roots of four sugar beet varieties in 2017/2018 and 2018/2019 seasons. The results obtained pointed out that the values of sodium percentage significantly affected by different Capillin levels. These differences may be attributed to soil properties. It could be noted that values of sodium Percentage in 500 ppm Capillin level was lower than those of 250 and 375 ppm levels. This result is in agreement with Allam et al. (2007) and Khalil et al. (2019). highest value of this trait was recorded by
Polybelga variety at Control Capillin level. 
The results are in agreement with those of $\mathrm{Abd}$ El-Kader (2011) who stated that the effect of growth regulators application pix and IAA on decreasing Sodium percentage. At 200 ppm IAA attained Sodium percentage (1.68\%). Pix at $2000 \mathrm{ppm}$ attained Sodium percentage $(1.82 \%)$. on the other hand, 500 ppm Capillin recoded the lowest Sodium percentage $(1.01 \%)$.

\subsubsection{Alfa amino-nitrogen root percentage:}

Results in Table (7) show the effect of the four Capillin levels (Control, 250, 375 and 500 ppm) on Alfa amino-nitrogen percentage in roots of four sugar beet varieties in 2017/2018 and 2018/2019 seasons.

Table 7. Alfa amino -nitrogen percentage of four sugar beet varieties as affected by Capillin le vels in $2017 / 2018$ and $2018 / 2019$ seasons.

\begin{tabular}{|c|c|c|c|c|c|c|c|c|c|}
\hline \multirow{3}{*}{$\begin{array}{l}\text { Season } \\
\text { Variety } \\
\end{array}$} & $2017 /$ & & & & $2018 /$ & 019 & & & \\
\hline & \multicolumn{9}{|c|}{ Capillin levels } \\
\hline & \multicolumn{2}{|c|}{ Control 250} & \multirow{2}{*}{$\frac{375}{1.79}$} & \multirow{2}{*}{$\frac{500}{1.96}$} & \multicolumn{2}{|c|}{ Control250 } & \multirow{2}{*}{$\begin{array}{l}\frac{375}{1.85} \\
\end{array}$} & \multirow{2}{*}{$\frac{500}{2.05}$} & \multirow[t]{2}{*}{$\mathrm{Ppm}$} \\
\hline Samba & 2.21 & 1.87 & & & 2.25 & 2.05 & & & \\
\hline Pleno & 2.29 & 1.89 & 1.82 & 2.00 & 2.23 & 2.10 & 1.92 & 2.08 & \\
\hline Gloria & 2.06 & 2.04 & 1.85 & 1.98 & 2.16 & 2.00 & 1.87 & 2.01 & \\
\hline Polybelga & 2.26 & 2.17 & 2.00 & 2.14 & 2.23 & 2.10 & 1.95 & 2.09 & \\
\hline \multicolumn{10}{|l|}{ L.S.D at $0.05 \%$} \\
\hline Capillin levels (L) & 0.090 & & & & 0.040 & & & & \\
\hline Varieties (V) & 0.130 & & & & 0.050 & & & & \\
\hline $\mathbf{L} \times \mathbf{V}$ & 0.220 & & & & 0.090 & & & & \\
\hline
\end{tabular}

\subsubsection{Quality traits:}

3.1.2.1. Sucrose percentage:

Results in Table (8) show the effect of the four Capillin levels (Control, 250, 375 and $500 \mathrm{ppm}$ ) on sucrose percentage of four sugar beet varieties in 2017/2018 and 2018/2019 seasons. The highest mean values of sucrose percentage was obtained from 500 ppm Capillin level for samba variety and polybelga in the first season and for samba variety in the second season (24.26, 24.33 and 24.92\%), respectively. These differences in sucrose
Results obtained cleared that there was a significant influence on the values of Alfa aminonitrogen percentage due to the growing Capillin levels. The results revealed that roots of sugar beet grown at Control contained higher Alfa aminonitrogen percentage compared to those grown at 250 and $375 \mathrm{ppm}$. These findings are in accordance $w$ ith Shalaby (2003), Allam et al. (2007) and Khalil et al. (2019). The maximum Alfa amino-nitrogen (\%) was recorded by Pleno sugar beet variety under Control Capillin levels, while the minimum Alfa aminonitrogen (\%) was reported by Samba sugar beet variety under 375 ppm Capillin level in both seasons. percentage may be due to the growing Capillin levels. Differences among varieties in sucrose percentage were signific ant (Table 8).

The results are in agreement with those of $\mathrm{Abd}$ El-Kader (2011) stated that the effect of growth regulators application pix and IAA on increasing sucrose percentage. At 200 ppm IAA sucrose percentage (17.7\%). Pix at $2000 \mathrm{ppm}$ attained sucrose percentage $(22.13 \%)$. On the other hand, $500 \mathrm{ppm}$ Capillin recorded the highest sucrose percentage $(24.92 \%)$.

Table 8. Sucrose (\%) of four sugar beet varieties as affected by Capillin levels in 2017/2018 and 2018/2019 seasons.

\begin{tabular}{|c|c|c|c|c|c|c|c|}
\hline \multirow{3}{*}{$\begin{array}{l}\text { Season } \\
\text { Variety }\end{array}$} & \multirow{2}{*}{\multicolumn{3}{|c|}{$\begin{array}{l}2017 / 2018 \\
\text { Capillin levels }\end{array}$}} & \multicolumn{4}{|l|}{ 2018/2019 } \\
\hline & & & & & & & \\
\hline & Control 250 & 375 & 500 & Control250 & 375 & 500 & ppm \\
\hline$\overline{\text { Samba }}$ & $21.34 \quad 22.78$ & 23.67 & 24.26 & $21.33 \quad 22.43$ & 22.99 & 24.92 & \\
\hline Pleno & $19.29 \quad 20.45$ & 21.64 & 22.46 & $19.22 \quad 21.43$ & 21.77 & 23.14 & \\
\hline Gloria & $19.00 \quad 20.15$ & 20.54 & 21.56 & $19.19 \quad 20.22$ & 20.83 & 22.75 & \\
\hline Polybelga & $20.88 \quad 22.35$ & 23.77 & 24.33 & $20.51 \quad 21.52$ & 21.75 & 23.26 & \\
\hline \multicolumn{8}{|l|}{ L.S.D at $0.05 \%$} \\
\hline Capillin levels (L) & 0.371 & & & 0.256 & & & \\
\hline Varieties (V) & 0.525 & & & 0.363 & & & \\
\hline$L \times V$ & 0.200 & & & 0.219 & & & \\
\hline
\end{tabular}

There is a positive correlation between juice purity and sucrose content. These findings are in accordance with Ismail et al. (2007), Shalaby et al. (2008), El-Sheikh et al. (2009) and Khalil et al. (2019).The results in Table (9) show that purity percentage of root was signific antly affected by the interaction between Capillin levels and varieties. These results could be indicating to the relative importance of the Capillin levels on juice quality. The results in table 9 pointed to a significant 
difference in purity percentage at the four Capillin levels. This result may be due to higher sucrose percentage (Table 8) and lower $\alpha$ - Amino $\mathrm{N}$ and potassium in root. This result is in agreement with the findings of El-Hinnawy et al. (2003), Aly (2006) and Khalil et al. (2019).

\subsubsection{Sugar loss to molasses percentage:}

Results in Table (10) show the effect of the four Capillin levels (Control, 250, 375 and 500 ppm) on percentage of sugar loss to molasses of four sugar beet varieties in 2017/2018 and 2018/2019 seasons. The results pointed out that growing under Capillin

Table 9. Purity \% of four sugar beet varieties as affected by Capillin levels in $2017 / 2018$ and 2018/2019 seasons.

\begin{tabular}{|c|c|c|c|c|c|c|c|c|c|}
\hline \multirow{3}{*}{$\begin{array}{l}\text { Season } \\
\text { Variety } \\
\end{array}$} & \multirow{2}{*}{\multicolumn{4}{|c|}{$\begin{array}{l}\frac{2017 / 2018}{\text { Capillin levels }} \\
\text { and }\end{array}$}} & \multicolumn{5}{|c|}{ 2018/2019 } \\
\hline & & & & & & & & & \\
\hline & \multicolumn{2}{|c|}{ Control 250} & \multirow{2}{*}{$\begin{array}{ll}375 \\
95.72\end{array}$} & \multirow{2}{*}{$\begin{array}{l}500 \\
96.31\end{array}$} & \multicolumn{2}{|c|}{ Control250 } & \multirow{2}{*}{$\begin{array}{l}375 \\
95.08\end{array}$} & \multirow{2}{*}{$\begin{array}{l}500 \\
95.94\end{array}$} & \multirow[t]{2}{*}{ ppm } \\
\hline Samba & 93.94 & 94.73 & & & 94.07 & 94.68 & & & \\
\hline Pleno & 93.32 & 94.28 & 95.4 & 95.45 & 93.49 & 94.41 & 94.94 & 95.85 & \\
\hline Gloria & 93.67 & 94.19 & 95.37 & 95.47 & 93.75 & 94.46 & 94.89 & 95.85 & \\
\hline Polybelga & 94.01 & 94.77 & 95.7 & 95.82 & 93.97 & 94.59 & 94.98 & 95.78 & \\
\hline L.S.D at $0.05 \%$ & & & & & & & & & \\
\hline Capillin levels (L) & 0.150 & & & & 0.104 & & & & \\
\hline Varieties (V) & 0.212 & & & & 0.147 & & & & \\
\hline $\mathbf{L} \times \mathbf{V}$ & 375 & & & & 0.256 & & & & \\
\hline
\end{tabular}

levels had a signific ant effect on percentage of sugar lost to molasses. Spray sugar beet at $500 \mathrm{ppm}$ resulted in less sugar loss to molasses percentage, compared to that sown at Control and250 ppm Capillin levels. This result could be attributed to higher sucrose percentage (Table 8), lower $\alpha-$ Amino $\mathrm{N}$ in roots (Table 7 ), higher purity percentage (Table 9) at 500 ppm compared to those recorded at Control and $250 \mathrm{ppm}$. Pleno variety recorded the highest value of this trait. On the other hand, samba had the lowest sugar loss to molasses percentage.

\begin{tabular}{|c|c|c|c|c|c|c|c|c|c|}
\hline Season & 2017 & & & & $/ 2018$ & 2019 & & & \\
\hline & Capil & leve & & & & & & & \\
\hline Variety & Cont & 250 & 375 & 500 & Cont & 250 & 375 & 500 & ppm \\
\hline Samba & 1.88 & 1.74 & 1.54 & 1.44 & 1.85 & 1.76 & 1.67 & 1.56 & \\
\hline Pleno & 1.90 & 1.73 & 1.54 & 1.58 & 1.85 & 1.77 & 1.66 & 1.53 & \\
\hline Gloria & 1.79 & 1.75 & 1.51 & 1.54 & 1.79 & 1.69 & 1.62 & 1.50 & \\
\hline Polybelga & 1.84 & 1.75 & 1.57 & 1.58 & 1.83 & 1.74 & 1.65 & 1.55 & \\
\hline L.S.D at $0.05 \%$ & & & & & & & & & \\
\hline Capillin levels (L) & 0.032 & & & & 0.018 & & & & \\
\hline Varieties (V) & 0.045 & & & & 0.025 & & & & \\
\hline $\mathbf{L} \times \mathbf{V}$ & 0.070 & & & & 0.435 & & & & \\
\hline
\end{tabular}

\subsubsection{Extractable sugar percentage:}

Results in Table (11) show the effect of the four Capillin levels (Control, 250, 375 and 500 ppm) on extractable sugar percentage of four sugar beet varieties in 2017/2018 and 2018/2019 seasons.

Extractable sugar was significantly affected by studied Capillin levels. Foliar spray of sugar beet by 500 ppm Capillin resulted in higher mean value extractable sugar percentage compared to Control and 250 ppm Capillin levels in both seasons. This result could be attributed to higher sucrose percentage (Table 8), lower $\alpha$ - Amino $\mathrm{N}$ in roots (Table 7) and higher purity percentage (Table 9) at 500 ppm Capillin levels. These results are in line with those reported by Allam et al (2007) and Khalil et al. (2019).
Samba variety recorded the highest value of this trait. On the other hand, Gloria variety had the low est extractable sugar percentage. The difference among varieties in this trait may be due to Capillin levels. These results are in agreement with Ramadan and Nassar (2004), Hoffmann et al. (2002), Aly (2006), Nasser, (2006), Ismail et al. (2007), Refay (2010)and Khalil et al. (2019). The highest value of this trait was given by spraying Samba variety by 500 ppm in both seasons. 
Table 11. Extraction sugar (\%) of four sugar beet varieties as affected by Capillin levels in 2017/2018 and 2018/2019 seasons.

\begin{tabular}{|c|c|c|c|c|c|c|c|c|c|}
\hline \multirow{3}{*}{$\begin{array}{l}\text { Season } \\
\text { Variety } \\
\end{array}$} & \multicolumn{4}{|c|}{$2017 / 2018$} & \multicolumn{5}{|c|}{ 2018/2019 } \\
\hline & \multicolumn{9}{|c|}{ Capillin levels } \\
\hline & \multicolumn{2}{|c|}{ Control 250 } & \multirow{2}{*}{\begin{tabular}{|l|}
375 \\
21.53
\end{tabular}} & \multirow{2}{*}{$\begin{array}{l}500 \\
22.22\end{array}$} & \multicolumn{2}{|c|}{ ControL50 } & \multirow{2}{*}{$\begin{array}{ll}375 \\
20.72\end{array}$} & \multirow{2}{*}{$\begin{array}{l}500 \\
22.76\end{array}$} & ppm \\
\hline Samba & 18.86 & 20.44 & & & 18.88 & 20.07 & & & \\
\hline Pleno & 16.79 & 18.12 & 19.50 & 20.28 & 16.77 & 19.06 & 19.51 & 21.01 & \\
\hline Gloria & 16.61 & 17.80 & 18.43 & 19.42 & 16.8 & 17.93 & 18.61 & 20.65 & \\
\hline Polybelga & 18.44 & 20.00 & 21.6 & 22.15 & 18.08 & 19.18 & 19.5 & 21.11 & \\
\hline \multicolumn{10}{|l|}{ L.S.D at $0.05 \%$} \\
\hline Capillin levels (L) & & & 0.369 & & 0.257 & & & & \\
\hline Varieties (V) & & & 0.521 & & 0.363 & & & & \\
\hline$L \times V$ & & & 0.910 & & 0.630 & & & & \\
\hline
\end{tabular}

3.1.2.4. Extractability percentage:

Results presented in Table (12) show the influence of four Capillin levels (Control, 250, 375 and 500 ppm) on extractability percentage of four sugar beet varieties. The results revealed that extractability percentage significantly affected by Capillin levels. 500 ppm Capillin level surpassed Control and 250 ppm Capillin levels in this respect. This result could be attributed to higher sucrose percentage (Table 8), lower $\alpha$ - Amino $\mathrm{N}$ in roots (Table 7) and higher

Table 12. Extractability \% of four sugar beet varieties as affected by Capillin levels in2017/2018 and 2018/2019 seasons.

\begin{tabular}{|c|c|c|c|c|c|c|c|c|c|}
\hline \multirow{3}{*}{$\begin{array}{l}\text { Season } \\
\text { Variety } \\
\end{array}$} & \multicolumn{4}{|c|}{$2017 / 2018$} & \multicolumn{5}{|c|}{$2018 / 2019$} \\
\hline & \multicolumn{9}{|c|}{ Capillin levels } \\
\hline & \multirow{2}{*}{$\begin{array}{l}\text { Control } \\
88.39\end{array}$} & \multirow{2}{*}{$\begin{array}{l}250 \\
89.73\end{array}$} & \multirow{2}{*}{\begin{tabular}{|l|}
375 \\
90.95
\end{tabular}} & \multirow{2}{*}{$\begin{array}{l}500 \\
91.59\end{array}$} & \multicolumn{2}{|c|}{ Control250 } & \multirow{2}{*}{\begin{tabular}{|l|}
375 \\
90.13
\end{tabular}} & \multirow{2}{*}{\begin{tabular}{|l|}
500 \\
91.32
\end{tabular}} & ppm \\
\hline Samba & & & & & 88.5 & 89.5 & & & \\
\hline Pleno & 87.06 & 88.62 & 90.1 & 90.28 & 87.24 & 88.93 & 89.64 & 90.82 & \\
\hline Gloria & 87.43 & 88.36 & 89.74 & 90.08 & 87.52 & 88.66 & 89.34 & 90.75 & \\
\hline $\begin{array}{l}\text { Polybelga } \\
\text { L.S.D at } 0.05 \%\end{array}$ & 88.29 & 89.51 & 90.85 & 91.04 & 88.16 & 89.13 & 89.66 & 90.77 & \\
\hline Capillin levels (L) & 0.003 & & & & 0.002 & & & & \\
\hline Varieties (V) & 0.004 & & & & 0.003 & & & & \\
\hline$L \times V$ & 0.204 & & & & 0.443 & & & & \\
\hline
\end{tabular}

3.2. - Yield:

3.2.1. Root yield (ton/fed.):

Results in Table (13) presented the effect of

Capillin levels (Control, 250, 375 and $500 \mathrm{ppm}$ )

and sugar beet varieties and their interaction on root yield per feddan in 2017/2018 and 2018/2019 seasons.

Table 13. Root yield (ton/fed) of four sugar beet varieties as affected by Capillin le vels in 2017/2018 and 2018/2019 seasons.

\begin{tabular}{|c|c|c|c|c|c|c|c|c|c|}
\hline \multirow{3}{*}{$\begin{array}{l}\text { Season } \\
\text { Variety }\end{array}$} & \multirow{2}{*}{\multicolumn{9}{|c|}{$\begin{array}{l}2017 / 2018 \\
\text { Capillin levels }\end{array}$}} \\
\hline & & & & & & & & & \\
\hline & \multirow{2}{*}{$\begin{array}{l}\text { Control } \\
23.67\end{array}$} & \multirow{2}{*}{$\begin{array}{l}250 \\
36.34\end{array}$} & \multirow{2}{*}{$\begin{array}{l}375 \\
38.77\end{array}$} & \multirow{2}{*}{$\begin{array}{l}\mathbf{5 0 0} \\
43.93\end{array}$} & \multicolumn{2}{|c|}{ Control250 } & \multirow{2}{*}{$\begin{array}{l}375 \\
39.33\end{array}$} & \multirow{2}{*}{$\begin{array}{l}\mathbf{5 0 0} \\
43.33\end{array}$} & \multirow[t]{2}{*}{ ppm } \\
\hline$\overline{\text { Samba }}$ & & & & & 25.72 & 37.30 & & & \\
\hline Pleno & 21.25 & 35.44 & 36.40 & 42.03 & 20.54 & 34.53 & 38.84 & 40.84 & \\
\hline Gloria & 25.27 & 35.40 & 40.20 & 43.62 & 24.27 & 39.40 & 40.25 & 40.25 & \\
\hline $\begin{array}{l}\text { Polybelga } \\
\text { L.S.D at } 0.05 \%\end{array}$ & 22.73 & 36.30 & 39.17 & 41.40 & 22.15 & 36.80 & 37.44 & 39.44 & \\
\hline Capillin levels (L) & 0.262 & & & & 0.320 & & & & \\
\hline Varieties (V) & 0.369 & & & & 0.460 & & & & \\
\hline L $\times$ V & \multicolumn{2}{|c|}{0.643} & & & 0.790 & & & & \\
\hline
\end{tabular}


Average root yield ton/fed was maximized when sugar beet treated by 500 ppm Capillin level compared with that treated by 250 and $375 \mathrm{ppm}$ Capillin.

The highest mean values of root yield (43.93 and 43.33 ton/fed) were found as a result of $500 \mathrm{ppm}$ Capillin level for samba variety in the first and second seasons, respectively, while the lowest mean values of root yield (21.25 and 20.54 ton/fed), respectively, resulted from pleno variety under Control Capillin level .

Results in Table (13) show that sugar beet varieties differed significantly in root yield/fed, in both seasons

The results are in agreement with those of Abd El-Kader (2011) stated that the effect of

Table 14. Sugar yield (ton/fed) of four sugar beet varieties as affected by Capillin levels in 2017/2018 and 2018/2019 seasons.

Season 2017/2018 2018/2019

Variety

\begin{tabular}{|c|c|c|c|c|c|c|c|c|c|}
\hline \multirow{3}{*}{ Samba } & \multicolumn{9}{|c|}{ Capillin levels } \\
\hline & \multirow{2}{*}{$\begin{array}{l}\text { Control } \\
5.05\end{array}$} & \multirow{2}{*}{$\begin{array}{l}250 \\
8.28\end{array}$} & \multirow{2}{*}{\begin{tabular}{|l|}
375 \\
9.18
\end{tabular}} & \multirow{2}{*}{$\begin{array}{l}500 \\
10.66\end{array}$} & \multicolumn{2}{|c|}{ Control250 } & \multirow{2}{*}{$\begin{array}{l}375 \\
9.04\end{array}$} & \multirow{2}{*}{$\begin{array}{l}500 \\
10.80\end{array}$} & \multirow[t]{2}{*}{ ppm } \\
\hline & & & & & 4.85 & 8.37 & & & \\
\hline Pleno & 4.10 & 7.25 & 7.88 & 9.44 & 3.95 & 7.40 & 8.46 & 9.45 & \\
\hline Gloria & 4.80 & 7.13 & 8.26 & 9.40 & 4.66 & 7.97 & 8.38 & 9.16 & \\
\hline Polybelga & 4.75 & 8.11 & 9.31 & 10.07 & 4.54 & 7.92 & 8.14 & 9.17 & \\
\hline \multicolumn{10}{|l|}{ L.S.D at $0.05 \%$} \\
\hline Capillin levels (L) & 1.09 & & & & 1.13 & & & & \\
\hline Varieties (V) & 1.53 & & & & 1.60 & & & & \\
\hline $\mathbf{L} \times \mathbf{V}$ & 2.50 & & & & 2.79 & & & & \\
\hline
\end{tabular}

attained the highest mean value of sugar yield/fed. These results are in line with Abd El-Razek et al. (2006), Aly (2006), Allam et al. (2007), Abd ElRazek (2012), El-Sheikh (2012) and Khalil et al. (2019). These results pointed to a significant variance among the tested sugar beet varieties in sugar yield ton/fed. Samba variety recorded the highest sugar yield per feddan producing (10.66) and (10.80) ton/fed in first and second seasons respectively. The superiority of Samba variety in sugar yield is results of producing highest root yield/fed and recording the greatest value of sucrose percentage and purity percentage in juice. The differences among the tested sugar beet varieties in sugar yield could be due to their root yield amount which is attributed to their quality structure i.e. ( $\mathrm{Na}$, $\mathrm{K}$ and Alfa amino-nitrogen percentage) and Capillin levels as a suitable to all of varieties.

The interaction between Capillin levels and sugar beet varieties exhibited significant effects on sugar yield per feddan. Samba variety treated with 500 ppm Capillin level attained the highest mean value of sugar yield in both seasons.

The results are in agreement with those of Abd ElKader (2011) stated that the effect of growth growth regulators application pix and IAA on increasing root yield ton/fed. At $200 \mathrm{ppm}$ IAA attained (28.3) root yield ton/fed. Pix at $2000 \mathrm{ppm}$ attained (25.9) root yield ton/fed. On the other hand, $500 \mathrm{ppm}$ Capillin recorded the highest (43.93) root yield ton/fed.

\subsubsection{Sugar yield (ton/fed):}

Results in Table (14) show sugar yield/fed of four sugar beet varieties as affected by the four Capillin levels (Control, 250, 375 and $500 \mathrm{ppm}$ ) in 2017/2018 and 2018/2019seasons. The results showed significant differences between the four Capillin levels in their effect on sugar yield/fed. It was found that sugar beet grown under $500 \mathrm{ppm}$

regulators application pix and IAA on increasing Sugar yield ton/fed. At $200 \mathrm{ppm}$ IAA sugar yield ton/fed (5.02). Pix at $2000 \mathrm{ppm}$ attained (5.75) Sugar yield ton/fed. On the other hand, $500 \mathrm{ppm}$ Capillin recorded the highest (10.80) Sugar yield ton/fed.

\subsubsection{Sugar ratio.}

Results in Table (15) show sugar ratio of four sugar beet varieties as affected by the four Capillin levels (Control, 250, 375 and 500 ppm) in2017/2018 and 2018/2019seasons. The results showed significant differences between the four Capillin levels in their effect on sugar ratio. Growing sugar beet Pleno variety gave the highest ratio under $500 \mathrm{ppm}$ Capillin level attained (230.24 and 239.24\%) in both seasons, respectively, compared with Control in Table (8).

The results are in agreement with those of Abd ElKader (2011) stated that the effect of growth regulators application pix and IAA on increasing sugar ratio. IAA at $200 \mathrm{ppm}$ recoded (145.5\%). Pix at $2000 \mathrm{ppm}$ recoded (166.6\%). On the other hand, $500 \mathrm{ppm}$ Capillin recoded the highest sucrose ratio $(239.24 \%)$. 
Mubarak M. H. and Deaa M. Abd El Rahman., 2020

Table 15. Sugar ratio four sugar beet varieties as affected by Capillin levels in 2017/2018 and 2018/2019 seasons.

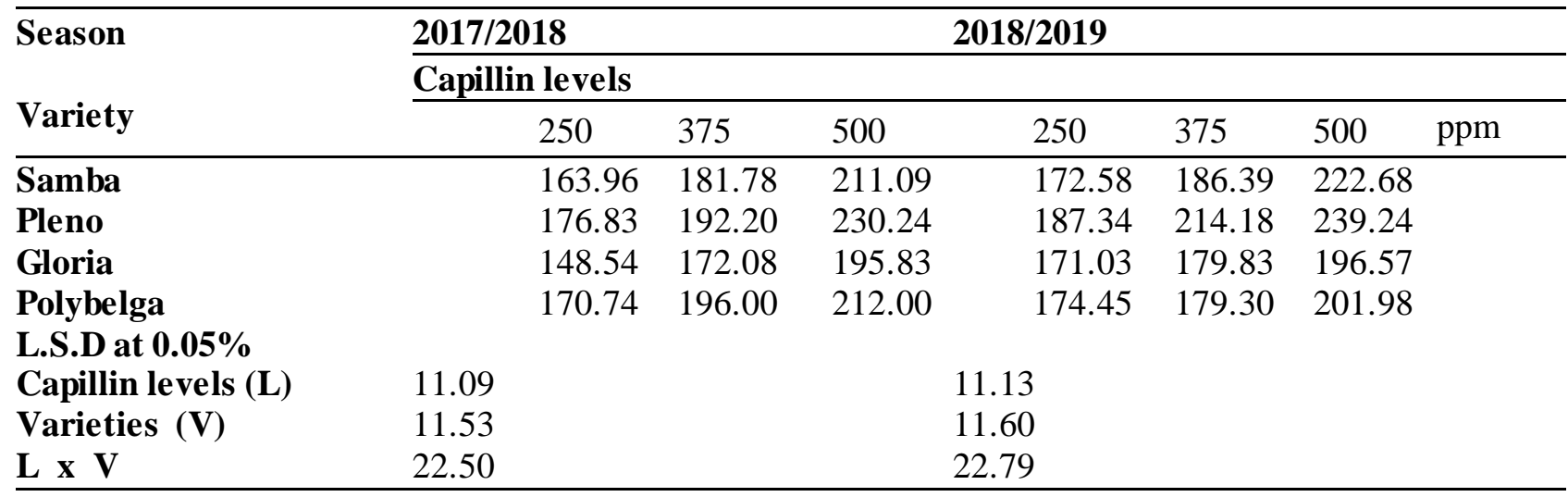

\section{Conclusion}

The increase of yields of top, root and sugar yields per fed due to increasing Capillin spray rate may be attributed to the favorable effects of Capillin on increasing leaf area per plant which led to increasing photosynthetic activity.

Generally, it could be recommended that fertilized sugar beet plants with $60 \mathrm{~kg} \mathrm{~N} / \mathrm{fed}$ and sprayed by Capillin at the concentration of $500 \mathrm{ppm}$ increased root and sugar yields/ fed under soil salinity equal $2720 \mathrm{ppm}$ and water of irrigation salinity equal $3550 \mathrm{ppm}$ at Arish, North Sinai Governorate conditions.

\section{REFERENCES}

Abashady, KhA, Zalat SS, Ibraheim MFM (2011). Influence of use nitrogen fertilizer levels and sources for late sowing date on yield and quality of sugar beet (Beta Vulgaris L.) in North Nile Delta. J. Plant Prod., Mansoura Univ., 2 (3): 425- 436.

Abd El-Kader EMA (2011). Effect of Nitrogen Fertilizer Rates and Some Growth Regulators Treatments on Sugar Beet. J. Plant Production, Mansoura Univ., Vol. 2 (12): 1693 - 1702.

Abd El-Razek AM( 2012). Response of sugar beet to nitrogen and potassium fertilization under two different locations. Egypt. J. Agric. Res., 90 (1): 155-172.

Abd El-Razek, A.M.; Al-Labbody, A.H.S. and Beshay MG (2006) Relative performance of some sugar beet varieties under three Geographic locations in Egypt. J. Appl. Sci., 21 (6 B):564-578.

Allam SM, Shalaby NMS, Al-Labbody AHS (2007). Yield and quality of ten sugar beet varieties grown in two locations. Egypt. J. Plant Breed., 11 (3): $111-134$.

Aly EF (2006). Effect of environmental conditions on productivity and quality of some sugar beet varieties. Ph.D. Thesis. Fac. Agric., Benha Univ., Egypt.

Aly EFA, Khalil SRA (2017).Yield, quality and stability evaluation of some sugar beet varieties in relation to locations and sowing dates. J. Plant Prod., Mansoura Univ., 8 (5): 611 - 616.

AOAC (1995). Association of Official Analytical Chemists.Official methods of analysis, 16th Ed., AOAC.Int., Washington. DC, USA.

Azzazy NB, Shalaby NMS, Abd El-Razek AM (2007). Effect of planting density and days to harvest on yield and quality of some sugar beet varieties under Fayoum Governorate condition .Egypt. J. Appl. Sci., 22 (12): 101-114.

Brown JD, Lilliand O (1964). Rapid determination of potassium and sodium in plant material and soil extracts by Flam photometry. Proc. Ame. Soc. Hort. Sci., 48: 341-346.

Carruthers A, Oldfield JFT, Teague HJ (1962). Assessment of beet quality. Paper Presented to the 15th Annual Technical Conference, British Sugar Corporation LTD. 36.

Devillers $P$ (1988). Prevision du sucremelasse. Scurries francases 129, 190-200. (CF The Sugar Beet Crop Book).

Dexter ST, Frankes M, Snyder FW (1967). A rapid of determining extractable white sugar as may be applied to the evaluation of agronomic practices and grower deliveries in the sugar beet industry. J. Am., Soc., Sugar Beet Technol., 14:433-454.

El-Hinnawy HH, Mamboed EA, Ramadan BSH, Farag MA (2003). Phenotypic stability for some sugar beet genotypes. Bull. Fac. Agric. Cairo Univ., $4: 1051-1059$.

El-Sheikh SRE (2012). Performance study of s ome sugar beet varieties under newly reclaimed lands in Egypt J. Biol. Chem.Environ. Sci., 7 (3): 507-517.

El-Sheikh SRE, Khaled KAM, Enan SAAM (2009). Evaluation of somesugar beet varieties under three harvesting dates. J. Agric. Sci., Mansoura Univ., 34 (3):1559-1567.

Gomez KA, Gomez AA (1984). Statistical Procedures for Agricultural Research.A Wiley Int. Sci. Public ation, John Wiley and Sons, New York.

Hoffmann C, Mahn K, Marylanders B (2002).Composition of harmful nitrogen in sugar beet (Beta vulgaris L.) amino acids, betaine, nitrate- 
as affected by genotype and environment European J. Agron., 22 (3): 255-265.

Khalil MR, Abd El-Razek AM, Abdalla MY, Mubarak MH (2019). Quality Of SomeSugarBeetVarietiesUnderDifferentEnvironmen talConditions. SINAI Journal of Applied Sciences, 1 :17-33.

Ismail AMA, Al-Labbody AHS, Shalaby NMS (2007). Evaluation of some sugar beet varieties under different combinations of NPK fertilizers Egypt. J. Appl. Sci.,22(3): 77-90.

Memon YM, Khan I, Panhwar RN (2004). Adoptability performance of some exotic sugarbeet varieties underagro-climatic conditions of Thatta. Pakistan Sugar J. , 19 (6), 42-46.

Mousa RA, Tagour RMH, Fakar AAO (2015). Efficacy of irrigation intervals and some weed control treatments on weeds and sugar beet (Beta vulgaris L.) productivity. Alex. J. Agric. Res., 60 (3): 253-268.

Nassar AMA (2006). Effect of sowing dates and thinning time on yield and quality of some monogerm and multigerm sugar beet varieties. Agric. Sc., Moshtohor, 44 (3): 833-845.

Ramadan BSH, Nassar AM (2004). Effect of nitrogen fertilization on yield and quality of some sugar beet varieties. Egypt. J. Agric. Res., 82 (3): 1253-1268.

Refay YA (2010) Root yield and quality traits of three sugar beet (Beta vulgaris L.) varieties in relation to sowing date and stand densities. World Journal of Agricultural Sciences 6 (5): 589-594.

Richard LA (1954). Diagnosis and Improvement of
Saline and Alkali Soils. US Department of Agriculture. Agricultural Handbook No. 60, Washington DC, 7-53.

Snedecor GW, Cochran WG (1990). Statistical Methods. 7th Ed. lowa State Univ. Press, AmesIowa, USA, pp. 507.

Selim MM, Al-Jawhara A Al-Owied (2017). Genotypic responses of pearl millet to integrated nutrient management. bioscience research, 14(2): 156-169.

Shalaby NM (2003) Effect of environmental conditions on the behaviors of different genotypes of sugar beet root yield and quality. Ph. D thesis Fac. of Agric. Al-Azhar Univ. Egypt.

Shalaby NMS, Al-Labbody AHS, El-Sheikh SER

(2008) Co variability of yield and quality of twenty sugar beet genotypes Egypt.J.Plant Breed. 12(1):267-277.

Sirsat MS, Cernadas E, Ernández-delgado MF, Khan R (2017). Classification of agricultural soil parameters in India.Computers and Electronics in Agric., 135: 269-279.

Turgut T (2012). Çeşit ve Lokasyon Farkllıklarının Şeker Pancarı (Beta vulgaris saccharifera L.)'nnVerim ve KaliteÖzelliklerine Etkilerinin Araştırılması. Namık Kemal Üniversitesi Fen Bilimleri Enstitüsü, Yüksek LisansTezi, 117 Sayfa.

Zaki, M.S. ; E. I. El-Sarag ; H. A. Maamoun and M. H.Mubarak(2018). Agronomic Performance Sugar Beet (Beta vulgaris L.) in Egypt Using Inorganic, Organic and Biofertilizers. Egypt.J.Agron. Vol. 40, No.1 ( 89-103). 


\section{الملخص العربي}

\section{تاثير رش الكابللين علي انتاجية وجودة بعض اصناف بنجر السكر \\ محمد حسن مبارك ' - ضياء الدين محمد عبدالرحمن' \\ 1قسم الإنتاج النباتي، كلية العلوم الزراعية البيئية، جامعة العريش، شمال سيناء، مصر \\ 20 بيدلى، وزارة الصحة}

تستخلص مادة الكابللين من نبات العادر ويعتبر الكابللين من المواد المضادة للفطريات والسرطان ومن المواد التي تعمل كمنظم

نمو للنباتات لانها تساعد علي انقسام وزيادة حجم الخلايا

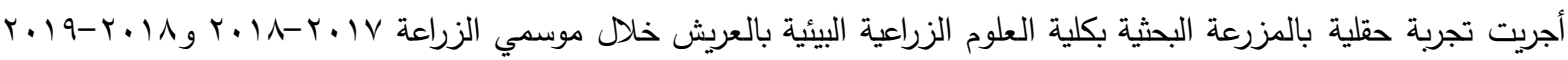

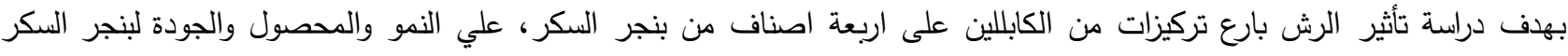

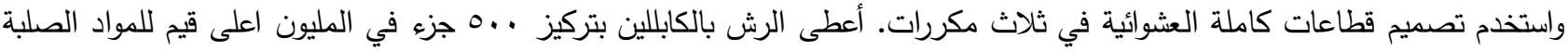
الذائة الكلية فى الموسم الاول، ومحصول السكر فى الموسم الثانى، ونسبة السكروز ونسبة النقاوة فى الموسمين.

• اعطي الصنف سامبا على محصول السكر فى الموسم الثانى بينما أثر على نسبة النقاوة ونسبة السكروز والمواد الصلبة الذائبة الكلية فى الموسمين. • أعطى التفاعل بين الصنف سامبا وتركيز الكابللين . جزء في المليون تأثيراً معنويا محصول السكر فى الموسم الاول، وأثر على نسبة النقاوة ونسبة السكروز و المواد الصلبة الذائبة الكلية فى الموسمين.

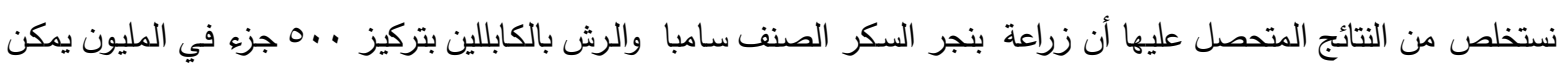
أن يوصي بها لزيادة محصول وجودة بنجر السكر تحت ظروف الاراضئ زراعة الرملية. 